\title{
Automation of lettuce seedlings irrigation with sensors deployed in the substrate or at the
} atmosphere

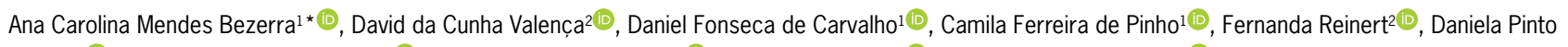

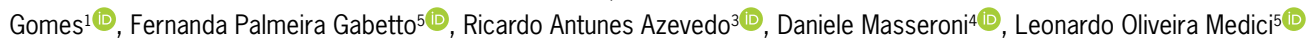

'Universidade Federal Rural do Rio de Janeiro - Depto. de Engenharia, Rod. BR 465, km 7 - 23897-000 - Seropédica, RJ - Brasil.

2Universidade Federal do Rio de Janeiro/Instituto de Biologia - Depto de Botânica, Av. Carlos Chagas Filho, 373 - 21941902 - Rio de Janeiro, RJ - Brasil.

3Universidade de São Paulo/ESALQ - Depto. de Genética, Av. Pádua Dias, 11 - 13418-900 - Piracicaba, SP - Brasil. 4Università degli Studi Di Milano - Dipto. di Scienze Agrarie e Ambientali, Via Giovanni Celoria 2 - 20133 - Milano - Italia. 5Universidade Federal Rural do Rio de Janeiro - Depto. de Ciências Fisiológicas.

*Corresponding author <anacarolina_mb@yahoo.com.br>

Edited by: Mohammad Valipour

Received May 14, 2017

Accepted October 23, 2017
ABSTRACT: Seedling production is an important step in the lettuce production system. However, there is a tendency to apply excessive irrigation at this stage. The aim of this study was to test the use of the Simplified Irrigation Controller (SIC) under two conditions: first, with the sensor installed in the substrate (measuring the soil water tension) and second, in the atmosphere ("atmospheric" - responding to vapor demand in the atmosphere) to control the irrigation of lettuce seedlings. The performance of the SIC was evaluated by monitoring plant traits. The lettuce seeds of the Regina cultivar were sown in styrofoam trays with commercial organic substrate. Both experiments were conducted under greenhouse conditions and evaluated under different SIC activation tensions. Shoot fresh weight and dry weight, height, number of leaves, leaf length, leaf area, water use efficiency (WUE) (ratio between the dry mass of plant produced by the volume of water applied), chlorophyll content, stomatal conductance and chlorophyll a fluorescence were assessed. In the experiment with the substrate sensor, the tension of $11.5 \mathrm{kPa}$ caused death in $94 \%$ of the seedlings and was disregarded in the statistical analysis. All biometric and physiological traits evaluated decreased as the SIC tensions increased. Thus, tensions of 4.0 (substrate sensor) and $3.5 \mathrm{kPa}$ (atmospheric sensor) showed greater potential for producing vigorous seedlings, with WUE average values of 1.86 and $1.37 \mathrm{~g} \mathrm{~L}^{-1}$, respectively. Cultivation of lettuce seedlings proved viable under both conditions when the SIC was used, with the emergence of a number of practical advantages of the atmospheric sensor over the substrate one.

Keywords: Lactuca sativa L., Simplified Irrigation Controller, water use efficiency

\section{Introduction}

The production of seedlings is an important step in the vegetable production process (Herrera et al., 2008). During germination and early development, plants are highly sensitive to environmental factors, especially as they are kept in containers with a small amount of soil, which limits the availability of water (and nutrients) (Carmona et al., 2012). Moreover, the use of irrigation systems is essential to greenhouse production since this is the only way to provide water to the crops. Thus, irrigation management plays a pivotal role, since it is important that water is applied at the proper time and in the appropriate volume, to avoid wasting water and nutrients (Dai et al., 2016).

Due to the increasing scarcity of water and the waste of water practiced by many farmers, there is great concern about the negative impacts of irrigation techniques on the productive sector, pointing to the need for a precise balance between agricultural productivity and the preservation of natural resources (Mojid et al., 2012). Given this scenario, studies relating to water economics are included in most sustainable types of irrigation management.

The Simplified Irrigation Controller (SIC) (Medici et al., 2010) is presented as an alternative in irrigation management, since the version used in the field (Batista et al., 2013; Gomes et al., 2017) can be adapted from the construction of sensors with reduced di- mensions and is suitable for use in the production of seedlings.

Although there are reports on the use of sensors based on automation of irrigation scheduling (Abdurrahman et al., 2015; Chaware et al., 2015), to the best of our knowledge, there is no study on the use of these sensors in seedling production, with the exception of our own previous report (Dias et al., 2013). Therefore, this study had as its main aim the evaluation of the effect of water irrigation management offered by this device first, with its sensor installed in the soil (based on the water availability in the substrate) and second, suspended in the atmosphere adjacent to the production trays (based on the variation of water vapor pressure), with different regulations (tensions), in the production of lettuce seedlings. The performance of the SIC was evaluated by monitoring several plant traits.

\section{Materials and Methods}

The use of the SIC ensures greater practicality and economy in irrigation. It is produced with a domestic filter candle (sensor), which is connected to a washing machine pressure switch through a flexible tube. With the tube filled with water, the pressure switch receives water column pressure while keeping the electric current interrupted. When the sensor humidity is reduced, negative pressure is generated on the filter candle, acting as a signal; this pressure is then transmitted to the pres- 
sure switch through the flexible tube, as per the Pascal Principle, causing the irrigation water supply to be electrically engaged.

From the moment the irrigation is triggered, water enters the sensor so as to bring the negative pressure value into equilibrium with the atmospheric pressure value. Furthermore, the water entering in the sensor also increases the pressure in the pressure switch so that it will turn off the irrigation system.

As previously stated, SIC uses a domestic filter candle as a sensor (Batista et al., 2013; Gomes et al., 2017; Medici et al., 2010); however, in this study the sensors were made with the original candle adapted to smaller dimensions, for the purpose of being used in seedling production systems. The dimensions of the substrate sensors were $3 \times 1 \times 1 \mathrm{~cm}$ and conical in shape for better insertion in the tray's cells, whilst the atmosphere sensors had dimensions of $4 \times 1 \times 1 \mathrm{~cm}$ and a parabolic shape. The adaptation consisted of cutting and sanding the original candle. Once the new sensor was ready and the SIC mounted, a test to measure the time it takes for the device to turn off was carried out by simulating a $30 \mathrm{~cm}$ difference between the pressure switch and the sensor and subsequently verifying how long it takes to react to a possible irrigation.

The greater the vertical distance, the faster the device uptakes water, leading to a faster switch off. Thus, a distance of $30 \mathrm{~cm}$ was set and used for the test because it was the shortest practical vertical distance for installing the SIC for the experiments. Consequently, in this case the device deactivates in a shorter period of time than at other settings. Furthermore, the vertical distance of $30 \mathrm{~cm}$ was the distance used for testing in the previous study by Dias et al. (2013). Throughout this test a shorter response time for the equipment was reached, compared to that previously found by Dias et al. (2013), dropping from 27 to $5 \mathrm{~s}$ (Dias et al., 2013).

The SIC is regulated by the difference between the height of the pressure switch and the candle. The vertical distance is proportional to the water tension (Medici et al., 2010; Gomes et al., 2017). For example, $30 \mathrm{~cm}$ of vertical distance corresponds to $3.0 \mathrm{kPa} ; 50 \mathrm{~cm}$ to 5.0 $\mathrm{kPa}$; and so on.

Aiming to facilitate the use of the sensor in the irrigation of seedlings the present study tested the use of the SIC by positioning the sensor in the atmosphere. Among the advantages of this positioning is the fact that, in the case of seedling irrigation, due to the reduced dimensions of the tray cells for the use of the developed equipment, it is necessary to make adaptations and because of the small size of the production cell there may not be adequate contact between the substrate and the ceramic, which is essential for correct measuring of the water tension. Another advantage is the greater mobility of the production trays, which would not be possible in the case where the sensor is located in the substrate.

\section{Site description}

Two experiments were carried out under greenhouse conditions in Seropédica, RJ, Brazil $\left(22^{\circ} 48^{\prime} 00^{\prime \prime} \mathrm{S}\right.$; $\left.43^{\circ} 41^{\prime} 00^{\prime \prime} \mathrm{W} ; 33.0 \mathrm{~m}\right)$. In the first experiment the SIC sensor was installed in the substrate (Figure 1A) while in the second, the equipment was evaluated with the ceramic sensor positioned above the substrate in the atmosphere adjacent to the production trays (Figure 1B).

The lettuce seedlings (Lactuca sativa cv. Regina) were sown in styrofoam trays (200 cells) with organic commercial substrate. The dimensions of each tray were: $67.4 \mathrm{~cm}$ long, $34.3 \mathrm{~cm}$ wide and $5.4 \mathrm{~cm}$ high.

\section{Irrigation management, treatments and experimental design}

Irrigation was performed with micro sprinklers installed $0.75 \mathrm{~m}$ away from each tray. A 0.5-hp pump picked up water from a 1000-L tank, installed at a height of $1 \mathrm{~m}$. A flow switch installed in the water outlet of the pump ensured its automatic activation at the moment when the SIC's drive tensions were reached.

The experimental design for the substrate sensor experiment was block randomization, comprising 6 blocks and four adjustments in the SIC $14.0 \mathrm{kPa}, 6.5 \mathrm{kPa}$, $9.0 \mathrm{kPa}$ and $11.5 \mathrm{kPa}$ ), totaling 24 experimental plots (Figure $2 \mathrm{~A}$ ). In the atmospheric sensor experiment with the SIC positioned in the air, a randomized block design was used in a factorial scheme where factor A comprised the four adjustments of the SIC $(3.5 \mathrm{kPa}, 5.0 \mathrm{kPa}, 6.5 \mathrm{kPa}$ and $8.0 \mathrm{kPa}$ ) and factor $\mathrm{B}$ the two evaluation periods (from 8 July to 8 Aug and 16 Sept to 16 Oct, both in 2016) with four replications, totaling 32 plots (Figure 2B).

The evaluation periods of the year were chosen because of the interest in evaluating the device with the sensor positioned in the air in different climatic conditions throughout the year.

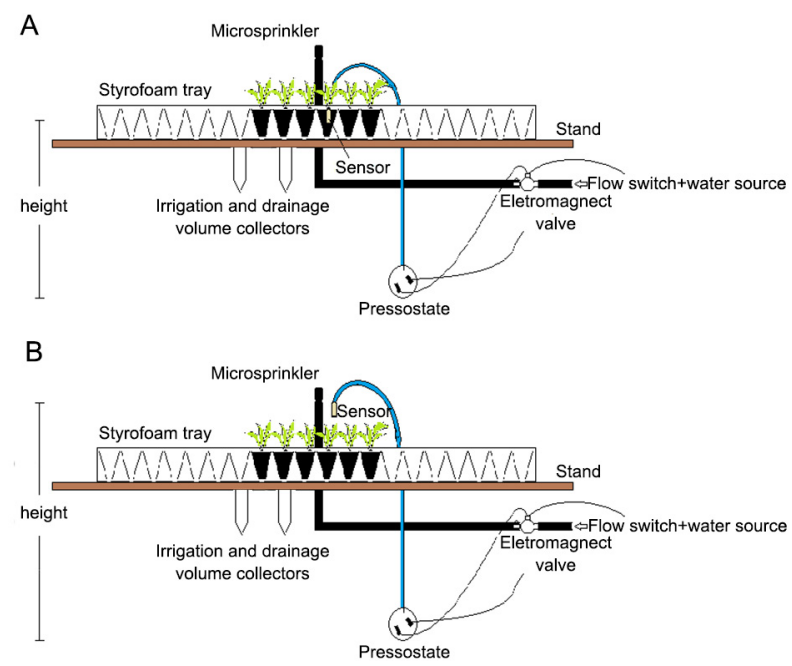

Figure 1 - SIC installed with the sensor positioned in the substrate (A) and SIC installed with the sensor positioned in the atmosphere adjacent to the trays (B). 


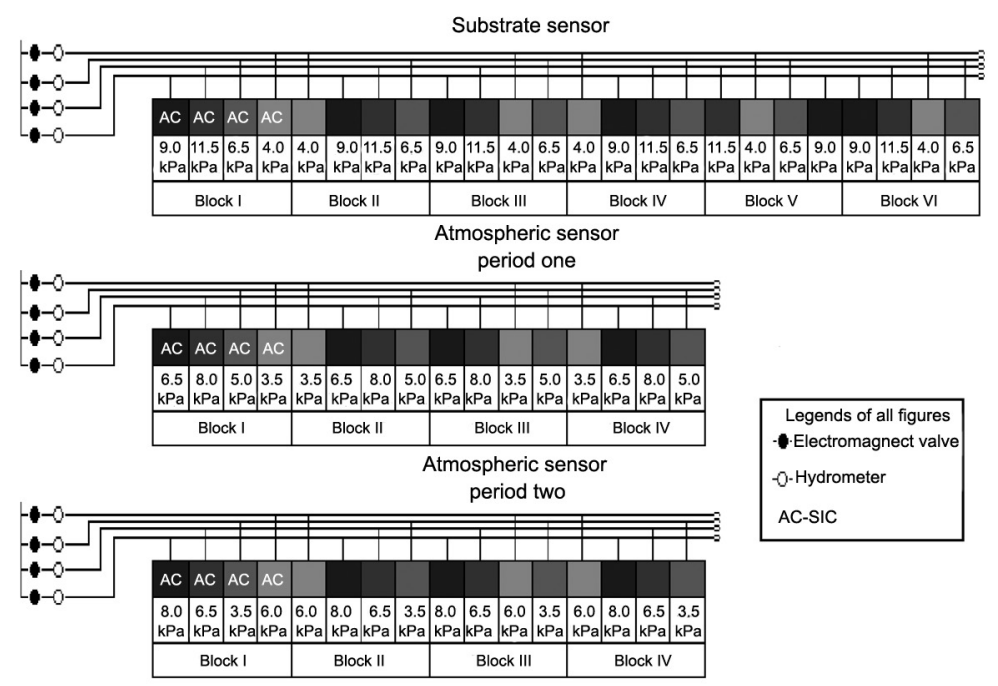

Figure 2 - Sketch of the experimental area.

The parcels of the first block received four SICs, each one related to a treatment. In the other plots the amount and time of irrigation were the same for each treatment which were triggered whenever irrigation was applied in the plots of the first block. Since each tray was irrigated by its own sprinkler, there was no overlap necessary for the application of water to be uniform throughout the tray. Thus, to warrant uniform application of water in the seedlings, only the 16 central cells were considered as useful plots.

To guarantee uniformity in the application of water among the trays of the same treatment, a preliminary test on the sowing was carried out. The test consisted of positioning four Falcon tube caps in a quadruple format over the edges of the working area, which contained the 16 production cells monitored in all trays of all the treatments. Next, the irrigation system was activated for $5 \mathrm{~min}$ and the volume of water collected in each tray was measured using a graduated cylinder. The volumes were compared with each other. The maximum variation of $10 \%$ between trays under the same treatment was stipulated in order to try to obtain the smallest possible variation.

Next, by using the same collectors that had been used in the previous test, the application uniformity test was carried out based on the test described by Christiansen (1942), aiming to guarantee $90 \%$ of uniformity in the trays.

\section{Estimated volume, germination and climate}

Each experimental plot received two Falcon $50 \mathrm{~mL}$ conical tubes. The tubes were placed randomly under two cells in the tray: one empty cell, to quantify the volume of water applied per cell, and another filled with substrate and seedling, in order to quantify drainage. This allowed for estimating the drainage and volume applied daily.
Seed germination occurred within the first five days after sowing (DAS). During the first eight DAS, manual and automatic irrigations were similar in all plots for the purpose of ensuring uniform germination. For automatic irrigation, in this period, all SICs were adjusted to $3.0 \mathrm{kPa}$. Greenhouse climate data were recorded by a USB temperature and humidity data logger (Impac, São Paulo, Brazil).

In the second period of the experiment with the atmospheric sensor, it was necessary to install shading screens $(50 \%)$ due to conditions of high temperature and light, which represented a limitation in seed germination and seedling survival.

\section{Evaluated traits}

In both experiments biometric traits of the seedlings and the amount of water used in their cultivation were evaluated. Therefore, shoot fresh and dry weight (SFW and SDW), height (H) and number of leaves (NL) were analyzed at 28 DAS. With the data of SDW and estimated water volume applied, water use efficiency (WUE) was calculated as a ratio of these two parameters.

Additional traits were evaluated for each experiment. In the substrate sensor experiment the following traits were also evaluated: leaf length, leaf area and chlorophyll content (Chl), whereas in the atmospheric sensor experiments stomatal conductance (gs) and analysis of the chlorophyll $a$ fluorescence transient parameters were also evaluated.

Leaf length and leaf area were evaluated at 15 DAS. This evaluation was carried out on two seedlings per tray.

Chlorophyll content (Chl) was monitored at 28 DAS. A Chlorophyll content meter, ChlorofiLOG (FALKER, Porto Alegre, Rio Grande do Sul, Brazil), was used for the Chl reading and the readings were taken on the expanded leaves. 
Stomatal conductance (gs) was measured at 25 DAS using a SC-1 Leaf Porometer (Decagon Devices, Washington, USA). Measurements were taken around $12 \mathrm{~h} 00$.

Fluorescence parameters were evaluated at 28 DAS. The measurements of chlorophyll fluorescence were taken using a portable Plant Efficiency Analyzer, the Handy PEA (Hansatech, Norfolk, UK). The measurements were taken in the middle third of fully expanded young leaves in the morning with dark adaptation. Fluorescence emission was induced in a $4 \mathrm{~mm}$ diameter of leaf area by exposing the sample to a pulse of saturating light at an intensity of $3.000 \mu \mathrm{mol} \mathrm{m} \mathrm{m}^{-2} \mathrm{~s}^{-1}$. From the fluorescence intensities, the parameters were calculated by the JIP Test, according to the methodology proposed by Strasser and Strasser (1995).

\section{Statistical analysis}

The results were submitted to analysis of variance at $p \leq 0.05$. In the presence of significant interaction, a sliced ANOVA was carried out for each factor. Scott-Knott's test was used to determine significance at $p \leq 0.05$. The data were analyzed with the aid of the Sisvar statistical program (Federal University of Lavras, Lavras, Brazil).

\section{Results}

We used two modes of detecting water demand by lettuce plants - a substrate sensor and an atmospheric sensor. Both systems proved to be efficient in the irrigation of lettuce seedlings, especially for the lowest tensions tested. Each seedling production consumed an average of 38.3 (substrate sensor) and $29.4 \mathrm{~mL}$ (atmospheric sensor). In the first experimental period with the atmospheric sensor no differences were observed in the biometric traits at all tensions tested.

Approximately $0 \%(4.0 \mathrm{kPa}), 8 \%(6.5 \mathrm{kPa}), 24 \%$ $(9.0 \mathrm{kPa})$ and $94 \%(11.5 \mathrm{kPa})$ of the seedlings died before the end of the experiment with the substrate sensor (Figure 3), whereas, all seedlings survived under the atmospheric sensor treatments.

\section{Irrigation management}

The different uses of SIC (substrate and atmosphere) provided different frequency and irrigation regimes. In the experiment with the substrate sensor the $4.0 \mathrm{kPa}$ (Figure 4A) tension provided irrigations almost daily. For the $6.5 \mathrm{kPa}$ tension (Figure 4B), irrigation events occurred on average every two days, while at the $9.0 \mathrm{kPa}$ tension (Figure $4 \mathrm{C}$ ) an average of three days were spent without irrigation, and at the $11.5 \mathrm{kPa}$ tension (Figure 4D) there was a period of five days without irrigation. This fact resulted in only five episodes of irrigation by SIC for this last treatment throughout the experimental period. As for the atmospheric sensor experiment, the irrigations occurred almost daily at all tension levels and periods tested (Figure 5A, B, C, D, E, F, G and $\mathrm{H})$ and the major difference observed was related to the volumes of water applied. The final higher volume of water applied to the lower tensions treatments may be the result of there being more than one irrigation event the same day.

\section{Biometric traits}

Tests at the lowest tensions tested, 4.0 (substrate sensor) and $3.5 \mathrm{kPa}$ (atmospheric sensor), showed greater potential for seedling production. SFW, SDW, H and NL presented reductions as the tested tension increased with the substrate sensor (Table 1). Due to the elevated death rate caused by the $11.5 \mathrm{kPa}$ tension with the substrate sensor, the results of this treatment were not considered for statistical analysis. In the experiment with the atmospheric sensor the second period tested produced more vigorous seedlings than the first one, exhibiting higher SFW, SDW, H and NL. On the other hand, greater differentiation between the traits considered according to the increase in tension evaluated in the second period was observed (Table 2).

\section{WUE}

WUE also showed a reduction as the tested tension increased, except for the first period of the

Table 1 - Shoot fresh weight; shoot dry weight; height; number of leaves; leaf length; leaf area; water use efficiency and chlorophyll b content of Lactuca sativa seedlings at different tension adjustments of the SIC during the experiment with the sensor positioned in the substrate.

\begin{tabular}{|c|c|c|c|c|}
\hline \multirow{2}{*}{ Traits } & \multicolumn{3}{|c|}{ Adjustment Tension of SIC (Simplified Irrigation Controller) } & \multirow{3}{*}{$\frac{11.5}{\mathrm{kPa}}$} \\
\hline & 4.0 & 6.5 & 9.0 & \\
\hline & & $-\mathrm{kPa}$ & 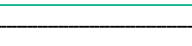 & \\
\hline Shoot Fresh Weight (g per plant) & $0.53 \pm 0.044 a$ & $0.13 \pm 0.050 \mathrm{~b}$ & $0.06 \pm 0.027 c$ & / \\
\hline Shoot Dry Weight (g per plant) & $0.07 \pm 0.005 a$ & $0.02 \pm 0.008 b$ & $0.01 \pm 0.005 c$ & / \\
\hline Height (cm) & $5.01 \pm 0.280 a$ & $2.77 \pm 0.618 b$ & $1.87 \pm 0.649 c$ & / \\
\hline Number of leaves (units) & $7.47 \pm 0.536 a$ & $5.19 \pm 0.935 b$ & $3.44 \pm 1.087 c$ & / \\
\hline Leaf length $(\mathrm{cm})$ & $16.08 \pm 3.758 \mathrm{a}$ & $10.89 \pm 2.276 b$ & $8.31 \pm 1.334 \mathrm{c}$ & / \\
\hline Leaf area $\left(\mathrm{cm}^{2}\right)$ & $47 \pm 17 \mathrm{a}$ & $17 \pm 5 b$ & $9 \pm 3 c$ & / \\
\hline Water Use Efficiency $\left(\mathrm{g} \mathrm{L}^{-1}\right.$ ) & $1.86 \pm 0.457 \mathrm{a}$ & $0.73 \pm 0.226 b$ & $0.45 \pm 0.091 c$ & / \\
\hline Chlorophyll b content (FCl - Falker chlorophyll index) * * & $1.98 \pm 0.102 \mathrm{a}$ & $3.35 \pm 0.968 b$ & $2.58 \pm 0.852 a$ & / \\
\hline Volume of water to produce a seedling $(\mathrm{L})$ & $0.04 \pm 0.006$ & $0.03 \pm 0.004$ & $0.03 \pm 0.004$ & / \\
\hline
\end{tabular}

Small caption letters at the rows represent significant differences using Tukey's test at $p<0.05 .{ }^{*} 11.5 \mathrm{kPa}$ tension caused death in $94 \%$ of the seedlings and was disregarded in the statistical analysis; **no difference was observed for Chlorophyll a (data not shown). 


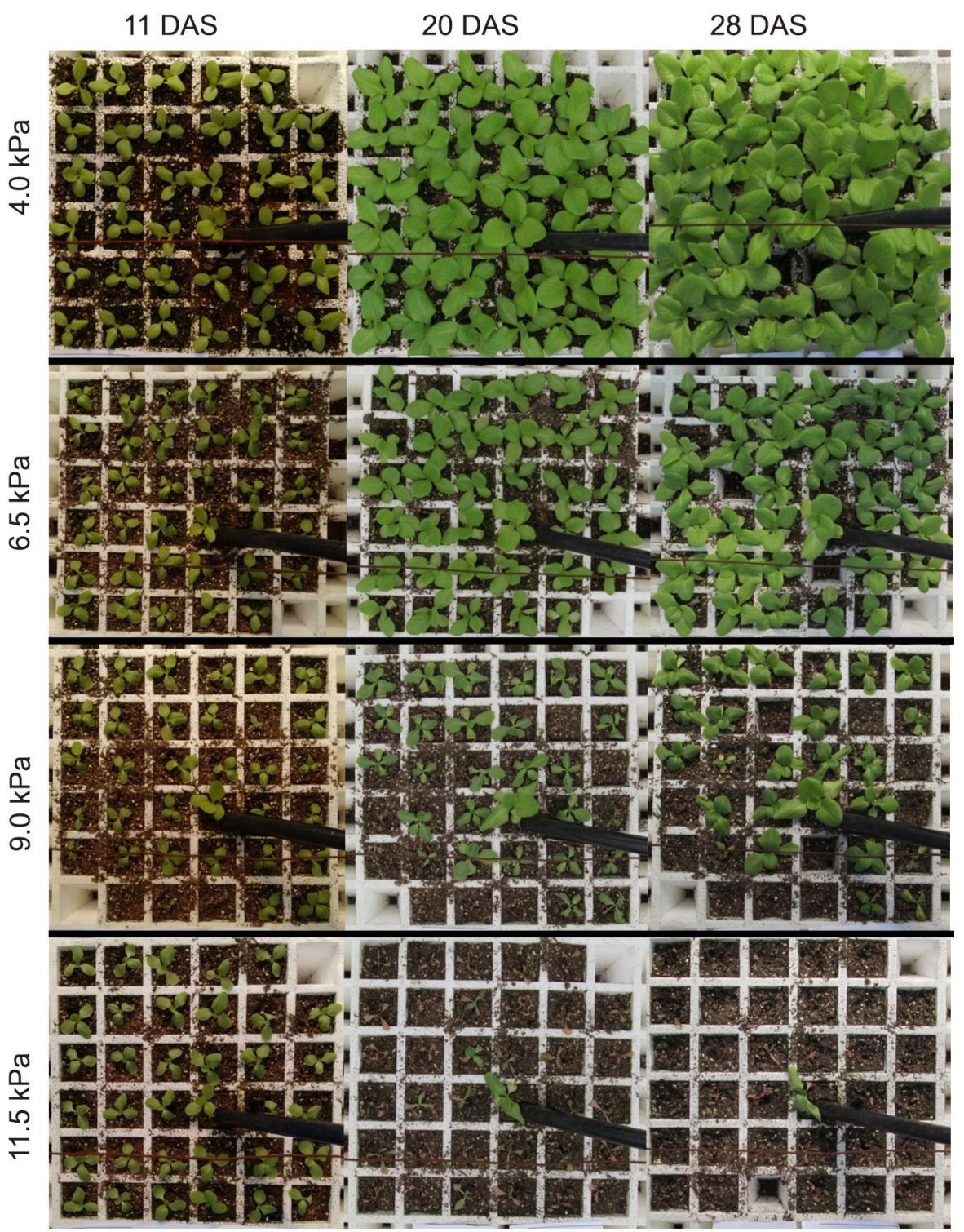

Figure 3 - Development of lettuce seedlings in trays of the first block (SIC block) at 11, 20 and 28 days after sowing (DAS) with the substrate sensor. Variation of shoot fresh weight values of $17.3 \%$.

atmospheric sensor (Tables 1 and 2). Tensions of 4.0 (substrate sensor) and $3.5 \mathrm{kPa}$ (atmospheric sensor) presented WUE with an average value of $1.86 \mathrm{~g} \mathrm{~L}^{-1}$ and $1.37 \mathrm{~g} \mathrm{~L}^{-1}$ (second experimental period), respectively.

\section{Other evaluated characteristics}

Substrate sensor experiment - Leaf length and leaf area data exhibited the same behavior as the previous variables, presenting increased reductions when subjected to tensions greater than $4.0 \mathrm{kPa}$ (Table 1). Chlorophyll content, measured 28 DAS (Table 1), climbed higher as the tension increased.
Atmospheric sensor experiment - The gs measured at 25 DAS decreased as a function of the regulated tension for the SIC in the second period. However, the gs values measured in the first period were very close for seedlings at 3.5, 5.0 and $6.5 \mathrm{kPa}$ tensions (Table 2).

No significance was observed in the isolated effect or interaction of the treatments tested in the parameters analyzed by the JIP test (data not show).

\section{Discussion}

\section{Irrigation management and death rate}

In both experiments, SIC activation was less frequent at higher tensions. It could be assigned to a certain 
Table 2 - Shoot fresh weight; shoot dry weight; height; number of leaves; water use efficiency and stomatal conductance of Lactuca sativa seedlings during the experiment with the atmospheric sensor at different tension adjustments and two experimental periods.

\begin{tabular}{|c|c|c|c|c|c|c|}
\hline & & \multirow{2}{*}{ Traits } & \multicolumn{4}{|c|}{ Adjustment Tension of SIC (Simplified Irrigation Controller) } \\
\hline & & & 3.5 & 5.0 & 6.5 & 8.0 \\
\hline \multirow{14}{*}{$\begin{array}{l}\frac{0}{0} \\
\frac{\circ}{0}\end{array}$} & 1 & \multirow{2}{*}{ Shoot Fresh Weight (g per plant) } & $0.21 \pm 0.065 B$ & $0.20 \pm 0.064$ & $0.20 \pm 0.042$ & $0.19 \pm 0.063$ \\
\hline & 2 & & $0.38 \pm 0.047 \mathrm{aA}$ & $0.24 \pm 0.028 b$ & $0.23 \pm 0.014 b$ & $0.14 \pm 0.021 c$ \\
\hline & 1 & \multirow{2}{*}{ Shoot Dry Weight (g per plant) } & $0.02 \pm 0.006 \mathrm{~B}$ & $0.02 \pm 0.005 B$ & $0.02 \pm 0.003$ & $0.01 \pm 0.004$ \\
\hline & 2 & & $0.04 \pm 0.004 \mathrm{aA}$ & $0.03 \pm 0.002 \mathrm{bA}$ & $0.02 \pm 0.001 \mathrm{c}$ & $0.01 \pm 0.006 \mathrm{c}$ \\
\hline & 1 & \multirow{2}{*}{ Height (cm) } & $4.06 \pm 0.342$ & $3.70 \pm 0.533 \mathrm{~B}$ & $3.69 \pm 0.348$ & $4.24 \pm 0.445 \mathrm{~A}$ \\
\hline & 2 & & $4.49 \pm 0.318 \mathrm{a}$ & $3.96 \pm 0.223 \mathrm{aB}$ & $3.80 \pm 0.235 b$ & $3.39 \pm 0.248 b B$ \\
\hline & 1 & \multirow{2}{*}{ Number of leaves (units) } & $5.25 \pm 0.614 \mathrm{~B}$ & $5.43 \pm 0.745$ & $5.78 \pm 1.026$ & $5.59 \pm 0.666 \mathrm{~A}$ \\
\hline & 2 & & $6.45 \pm 0.592 \mathrm{aA}$ & $5.60 \pm 0.693 b$ & $5.33 \pm 0.249 b$ & $4.51 \pm 0.382 \mathrm{cB}$ \\
\hline & 1 & \multirow{2}{*}{ Water Use Efficiency ( $\mathrm{g} \mathrm{L}^{-1}$ ) } & $0.77 \pm 0.177 \mathrm{~B}$ & $0.75 \pm 0.129 B$ & $0.74 \pm 0.062$ & $0.71 \pm 0.170$ \\
\hline & 2 & & $1.37 \pm 0.236 \mathrm{aA}$ & $1.12 \pm 0.083 \mathrm{bA}$ & $0.90 \pm 0.070 c$ & $0.88 \pm 0.270 c$ \\
\hline & 1 & \multirow{2}{*}{ Stomatal conductance $\left(\mathrm{mmol} \mathrm{m} \mathrm{m}^{-2} \mathrm{~s}^{-1}\right)$} & $261.5 \pm 20 \mathrm{aB}$ & $228.6 \pm 26 \mathrm{aB}$ & $221.1 \pm 42 \mathrm{a}$ & $120.2 \pm 32 b$ \\
\hline & 2 & & $444.5 \pm 42 \mathrm{aA}$ & $296.3 \pm 47 b A$ & $178.6 \pm 42 c$ & $109.9 \pm 40 d$ \\
\hline & 1 & \multirow{2}{*}{ Volume of water to produce a seedling (L) } & 0.025 & 0.027 & 0.027 & 0.014 \\
\hline & 2 & & 0.029 & 0.027 & 0.027 & 0.011 \\
\hline
\end{tabular}

Small caption letters at the rows represent significant differences using Tukey's test at $p<0.05$ and upper case letters at the columns represent significant differences using the F-test at $p<0.05$.
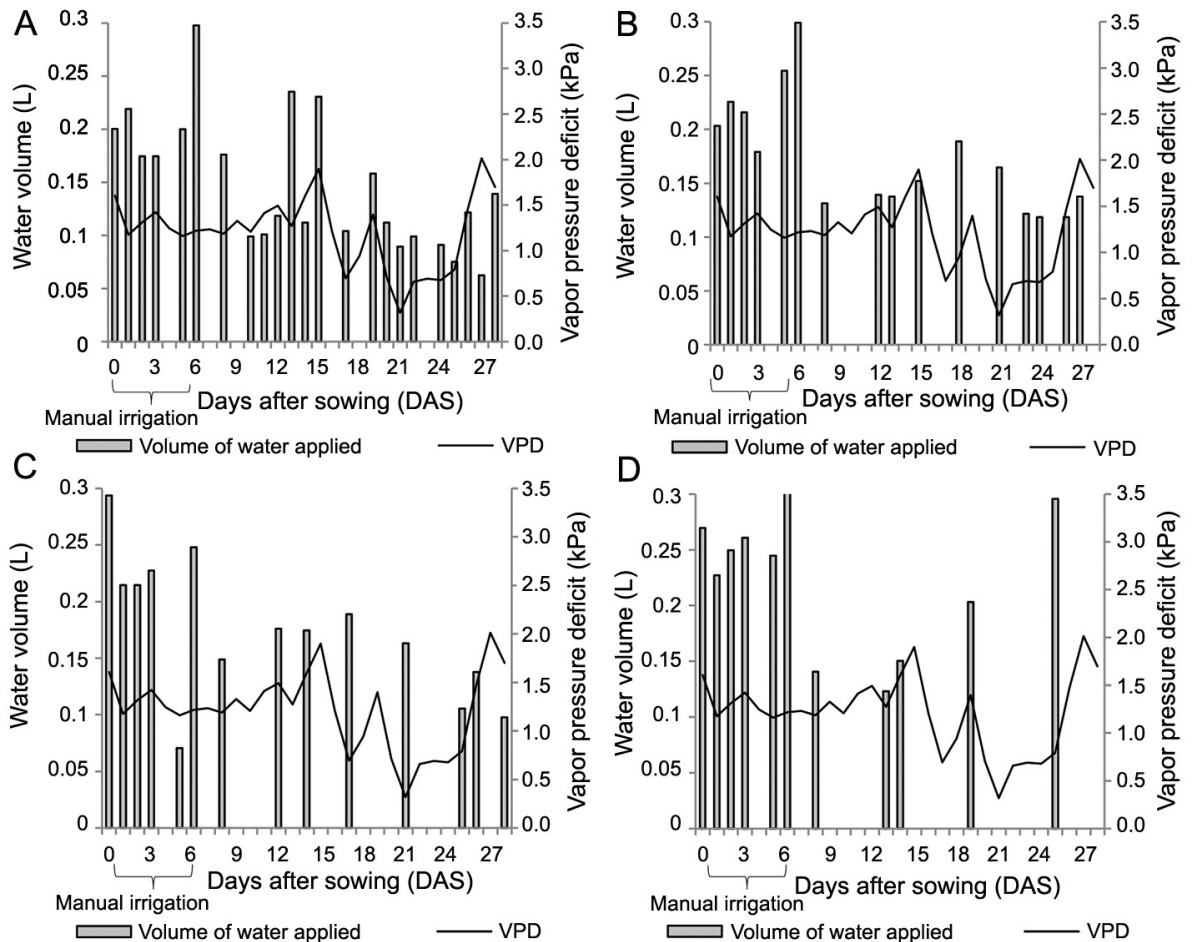

Figure 4 - Volumes of water applied during the experiment with the sensor positioned in substrate in the following tensions: $4.0 \mathrm{kPa}(\mathrm{A}) ; 6.5 \mathrm{kPa}$ (B); $9.0 \mathrm{kPa}(\mathrm{C})$ and $11.5 \mathrm{kPa}$ (D). Each bar represents the sum of the volume of water applied in the trays of the respective treatments daily, 16 plants per tray and 6 repetitions (blocks).

resistance of the ceramic material especially at higher tensions, because the water will find greater resistance to flow between the smaller pores, whereas at lower tensions this would not necessarily occur since due to the greater initial amount of available water, the water would flow through the larger pores facilitating hydrau- lic conductivity. The rapid decrease in conductivity occurs because the larger pores are emptied first.

This process is similar to the loss of water by the soil itself, with concepts similar to saturated flow, when the bigger pores are filled with water and the hydraulic flow occurs more easily due to the action of the gravita- 

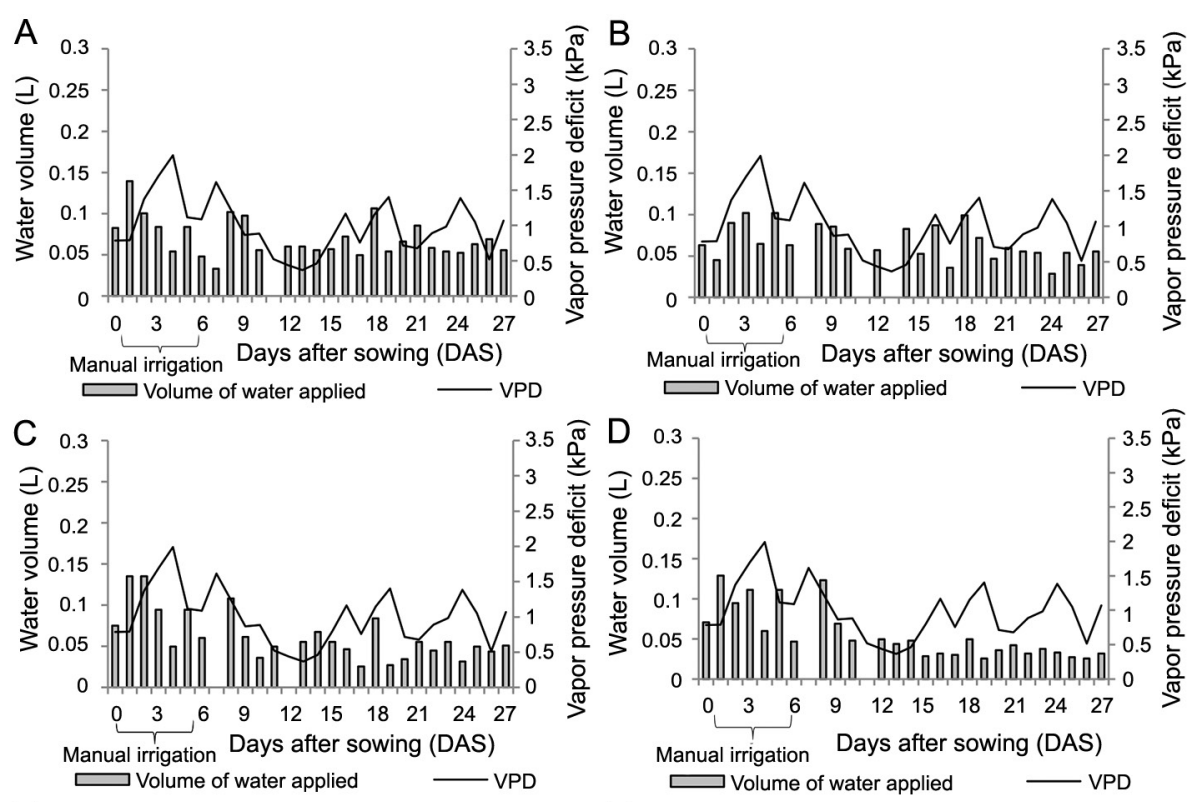

Manual irrigation Days after sowing (DAS)

Volume of water applied $\quad$ VPD
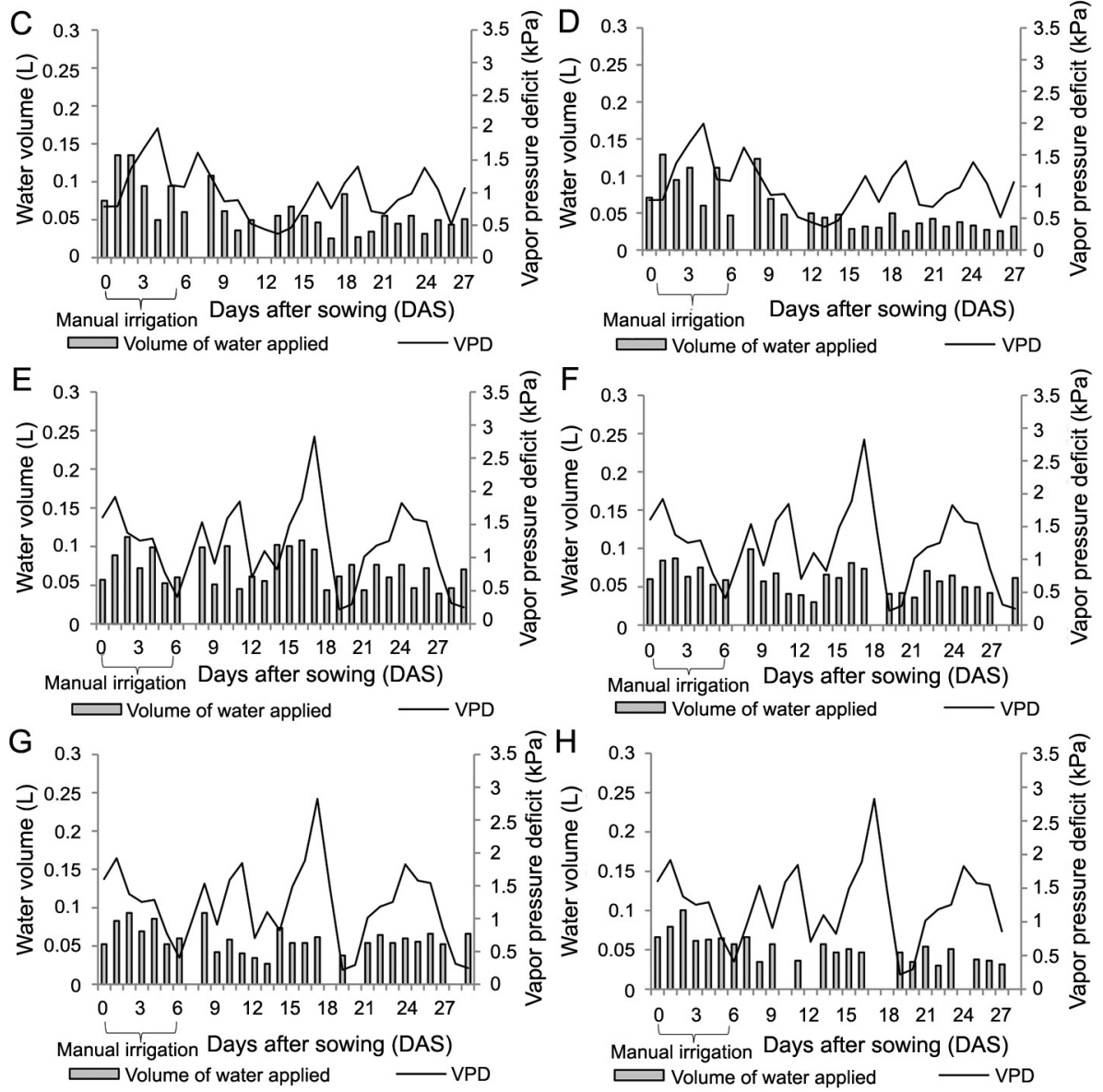

Figure 5 - Volumes of water applied during the experiment with the atmospheric sensor at different tensions and two experimental periods. First period: $3.5 \mathrm{kPa}$ (A) $5.0 \mathrm{kPa}$ (B) $6.5 \mathrm{kPa}$ (C) $8.0 \mathrm{kPa}$ (D). Second period: $3.5 \mathrm{kPa}$ (E) $5.0 \mathrm{kPa}$ (F) $6.5 \mathrm{kPa}$ (G) $8.0 \mathrm{kPa}(\mathrm{H})$. Each bar represents the sum of the volume of water applied in the trays of the respective treatments daily, 16 plants per tray and 4 repetitions (blocks).

tional potential, and unsaturated flow, as drainage proceeds the smaller pores empty out and the conductivity decreases (Beven and Germann, 1982; Nielsen et al., 1986).

When comparing atmospheric with substrate sensors, a lower frequency of water application and reduction in the seedlings growth were observed as the tension increased when the substrate sensor was used. When the sensor is installed in the substrate the loss of water from the SIC is slower compared to the sensor placed in the atmosphere due to the fact that the water flow will be subjected to different resistances from the substrate, added to the fact that at higher tensions the porous nature of the sensor material also leads to greater resistance, as discussed above. Differential climatic conditions between experiments may also be responsible for the differences observed (Figure 6A, B and C).

The experiment with the substrate sensor tensions greater than $4.0 \mathrm{kPa}$ also interfered negatively in seedling growth (Table 1). About $0 \%(4.0 \mathrm{kPa}), 8 \%(6.5 \mathrm{kPa})$, $24 \%(9.0 \mathrm{kPa})$ and $94 \%(11.5 \mathrm{kPa})$ of the seedlings did not complete the 28-day period and died before the end 

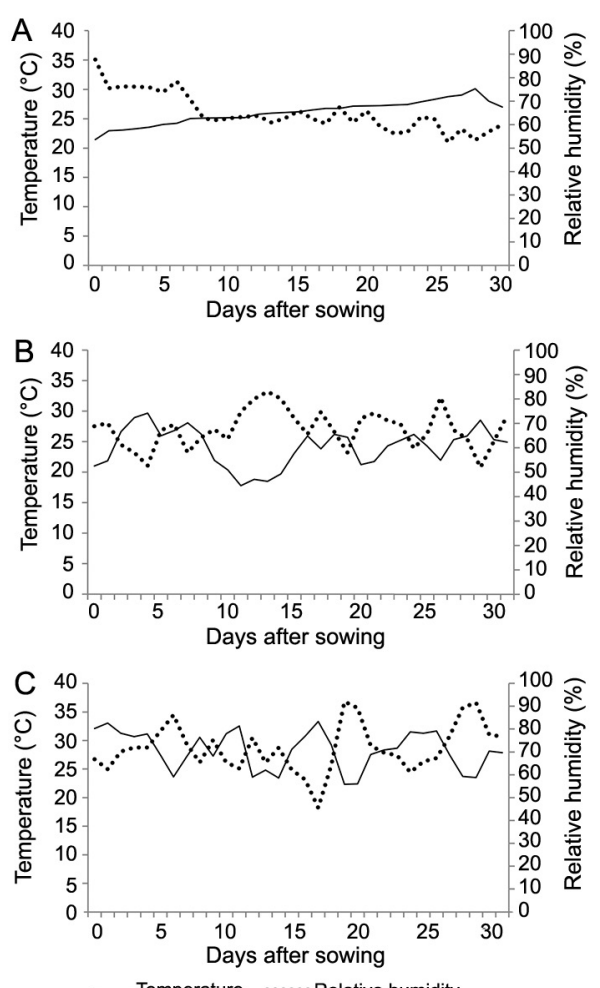

-Temperature $\ldots . .$. Relative humidity

Figure 6 - Mean values of temperature and relative humidity: experiment with the substrate sensor (A); experiment with the atmospheric sensor in the first (B) and second (C) experimental periods.

of the experiment. In fact, the irrigation regime with the highest tension tested in this study $(11.5 \mathrm{kPa})$ seriously impaired the development of lettuce seedlings. Furthermore, the seedlings of the cells with the sensor (trays of block I) exhibited greater vigor in relation to the others and this difference increased as the tension escalated. This evidence could be explained by the fact that the diaphragm of the pressure switch stores water and releases it to the cell where the sensor is installed as the tension is raised throughout its operation. This would act like a buffering of the tension in the sensor cell and prevent these seedlings from suffering the effects of the water restriction that is observed in the other cells.

This fact is important for the other applications of the SIC, since it emphasizes that the cells of the first block in which the sensors are installed will have a volume of stored water that will not be easily lost to the atmosphere, while in the other cells this same volume will be available only in the substrate. Due to these facts, even though the SIC is regulated for a certain tension, the other plants will actually be receiving a higher tension, which can lead to different WUE values (Gomes et al., 2017).

With the sensor positioned in the atmosphere adjacent to the production trays, the sensor would lose moisture as a function of the vapor pressure deficit (VPD) in this environment, and would communicate the reduction in internal pressure to the pressure switch, which would act by activating the irrigation. However, since the trend of water movement is always towards the most negative potential, which ends up being the potential of the atmosphere, it would be possible for the equipment to remain connected continuously. Yet, this fact was not observed in practice and still no drainage was observed during the whole experimental period, demonstrating that the system was functioning adequately.

Such a fact can also be attributed to the storage of water in the pressure switch that generates tension buffering. Thus, when receiving the water, the pressure switch holds it inside for a certain period, until the tension regulated by the SIC is reached, when it is greater than the tension in question.

\section{Biometric traits}

Lettuce seedlings presented superior performance at the $4.0 \mathrm{kPa}$ with the substrate sensor tension in the traits of SFW, SDW, $\mathrm{H}$ and $\mathrm{NF}$, when comparing data from all experiments. However, there was a marked reduction for all biometric traits as the water tension in the substrate sensor increased, which was not observed with the atmospheric sensor. Thus, the use of tensions higher than $4.0 \mathrm{kPa}$ with a substrate sensor would not be ideal, as it can impair the growth and survival of seedlings.

In view of the specificity of the vegetable seedling production system, with small volume production cells and water retention capacity, the use of an atmospheric sensor can act by binding the irrigation system and maintaining seedlings with high water content in the substrate.

SFW, SDW, $\mathrm{H}$ and NL showed better performance for the $4.0 \mathrm{kPa}$ (substrate sensor) and $3.5 \mathrm{kPa}$ tensions (atmospheric sensor) in relation to the other tested tension levels. These results were relatively higher or very close to those reported by Leal et al. (2011) and lower than in other studies (Castoldi et al., 2014; Gonçalves et al., 2014). Such larger production in other studies can be related to the use of trays with larger cells. Usually the use of trays with fewer cells is associated with larger seedlings being obtained as reported by Costa et al. (2012), Leal et al. (2011) and Oliveira et al. (2012), where the largest seedlings were obtained in cells of higher volume. Additionally, differences can be attributed to different climatic conditions or to varietal differences in morphological characteristics among cultivars.

It is worth noting the need to install a $50 \%$ shading screen in the second period analyzed with the atmospheric sensor, due to the conditions of higher temperature and radiation. With the use of shading screens, it is possible to observe productivity increases in regions where temperature and light conditions tend to be limiting. These responses, if the reduction in radiation is not excessive, may possibly enhance crop productivity and its quality (Ahemd, 2016; Gent, 2007; Sinclair et al., 1992). 
Similarly, the results indicate that high temperature and radiation effects can be minimized when a shade screen is used during the periods where these factors tend to be harmful to seedling development. Screen shading protection produced more vigorous seedlings when production should be reduced. Although no comparison was made between shade and non-shade production at the same time of production, the combined effect of the use of shading screen and the choice of climate-adapted cultivar may have been responsible for the better result observed in this period when the atmospheric sensor was in use.

\section{WUE}

WUE was also reduced at tensions greater than $4.0 \mathrm{kPa}$ (substrate sensor) and $3.5 \mathrm{kPa}$ (atmospheric sensor), presenting values of $1.86 \mathrm{~g} \mathrm{~L}^{-1}$ and $1.37 \mathrm{~g} \mathrm{~L}^{-1}$, respectively. Volumes of 38.3 (substrate sensor) and 29.4 $\mathrm{mL}$ (atmospheric sensor) were required for the production of a seedling. The value is close to those found by Santos et al. (2015) for the cultivation of adult lettuce plants in pots.

In the first experimental period, WUE was around $0.75 \mathrm{~g} \mathrm{~L}^{-1}$ for all the tensions tested. This was expected since there was no great variation in the growth rate of the seedlings nor the quantity of water supplied to the seedlings for the traits evaluated. Since the plants received daily amounts of water, the milder climate with less intensity of incident solar radiation allowed the plants to have similar growth conditions even if some of them received less water.

Few studies have assessed the efficient application of water in the production of seedlings of any species, as presented by Scalon et al. (2011) who evaluated the physiological WUE in mutambo (Guazuma ulmifolia Lam.) seedlings. Scalon et al. (2011) calculated WUE based on the ratio between the photosynthetic rate and the transpiration rate, but in this study the calculation was made on the dry mass of plant produced by the volume of water applied, which represents WUE in agronomic terms. For this reason, any comparison would be inappropriate. No literature was found to allow comparison of WUE values in lettuce seedlings.

\section{Other characteristics evaluated}

\section{Substrate sensor experiment}

Leaf length and leaf area - Leaf length and leaf area data also showed a decrease when subjected to tensions greater than $4.0 \mathrm{kPa}$ (Table 1). The value of leaf area found for the $4.0 \mathrm{kPa}\left(47 \mathrm{~cm}^{2}\right)$ tension is close to the highest values found by Trani et al. (2004) for the same development time of the seedlings. These same authors reported a reduction in leaf area values with the use of trays with more cells (288 cells) compared to trays with fewer cells (200 cells).
Chlorophyll content - Chlorophyll b content increased at higher tensions. The higher tensions led to the production of smaller seedlings and consequently smaller leaf area (Table 1). The magnitude of the leaf area is directly related to the arrangement of the chlorophyll pigment in the leaves, interfering in the concentration of these molecules when considering a particular reading area. The increase in chlorophyll concentration through water stress was also observed for Plantago ovata Forsk by Rahimi et al. (2013) and for Salix spp. by Weih et al. (2011). No difference was observed for chlorophyll a (data not show).

\section{Atmospheric sensor experiment}

Stomatal conductance (gs) - Stomatal conductance (gs) exhibited reduction in the second experimental period, declining as irrigation levels decreased (Table 2). This fact can be seen in both time periods. However, in the first experimental period with the atmospheric sensor it is notable that although there was a substantial decrease in gs among the $3.5 \mathrm{kPa}, 5.0 \mathrm{kPa}$ and $6.5 \mathrm{kPa}$ treatments, it was significant only when compared to the $8.0 \mathrm{kPa}$ tension.

The higher water availability provided greater stomatal opening, offering better conditions for physiological processes. This result is also reflected in the results observed in the analyzed biometric traits, showing the negative influence of the stomatal closure due to lower water availability in the growth of the seedlings. The results are also in agreement with several reports in the literature (Anjum et al., 2011; Chartzoulakis et al., 2002; Kato and Okami, 2011; Kim et al., 2004).

Analysis of the chlorophyll $a$ fluorescence transient - The $3.5 \mathrm{kPa}$ treatment which provides greater volume of water was adopted as control in both experimental times. No significance was observed for the isolated effect or for interaction for the treatments tested in the parameters analyzed through the JIP test. Thus, the results do not suggest any damage to the photosynthetic apparatus, although photosynthetic performance appears to improve as the irrigation volumes tested increased (data not shown).

\section{Conclusions}

The substrate sensor measured the water tension in the root system, which is the well-established tradition. However, the use of an atmospheric sensor can act by turning on the irrigation system and maintaining seedlings with higher water content in the substrate, which would be more highly recommended due to its more regular operation, which applies lower volumes of water at a time and activates more times over the production cycle. The practical use of the system with the atmospheric sensor is also a positive point in its favor. 
The tensions of 4.0 (substrate) and 3.5 (atmosphere) $\mathrm{kPa}$ showed higher potential for the production of more vigorous seedlings. The SIC was shown to be efficient in irrigation management and its use with the sensor positioned in the atmosphere showed promising results that can serve as basic data for future research aimed at relating operation and viability of use under different climatic conditions.

\section{Acknowledgments}

The authors thank the Programa de Pós-Graduação em Engenharia Agrícola e Ambiental at Universidade Federal Rural do Rio de Janeiro (UFRRJ) for their support of this research. The Governmental agencies Fundação de Amparo à Pesquisa do Estado do Rio de Janeiro (FAPERJ) for research funding and Conselho Nacional de Desenvolvimento Científico e Tecnológico (CNPq) for the research fellowships (D.F.C., L.O.M. and R.A.A.).

\section{Authors' Contributions}

Conceptualization: Bezerra, A.C.M., Valença, D.C., Medici, L.O. Data acquisition: Bezerra, A.C.M., Valença, D.C., Gabetto, F.P. Data Analysis: Bezerra, A.C.M., Valença, D.C., Gomes, D.P. Design of methodology: Medici, L.O. Writing and Editing: Bezerra, A.C.M., Valença, D.C., Carvalho, D.F.C., Pinho, C.F., Reinert, F., Gomes, D.P., Azevedo, R.A., Masseroni, D., Medici, L.O.

\section{References}

Abdurrahman, M.A.; Gebru, G. M.; Bezabih, T.T. 2015. Sensor based automatic irrigation management system. International Journal of Computer and Information Technology 4: 532-535.

Ahemd, H.A.; Al-Faraj, A.A.; Abdel-Ghany, A.M. 2016. Shading greenhouses to improve the microclimate, energy and water saving in hot regions: a review. Scientia Horticulturae 201: 3645.

Anjum, S.A.; Xie, X.; Wang, L.; Saleem, M.F.; Man, C.; Lei, W. 2011. Morphological, physiological and biochemical responses of plants to drought stress. African Journal of Agricultural Research 6: 2026-2032.

Batista, S.C.O.; Carvalho, D.F.; Rocha, H.S.; Santos, H.T.; Medici, L.O. 2013. Production of automatically watered lettuce with a low cost controller. Journal of Food, Agriculture and Environment 11: 485-489.

Beven, K.; Germann, P. 1982. Macropores and water flow in soils. Water Resources Research 18: 1311-1325.

Carmona, E.; Moreno, M.T.; Avilés, M.; Ordovás, J. 2012. Use of grape marc compost as substrate for vegetable seedlings. Scientia Horticulturae 137: 69-74.

Castoldi, G.; Freiberger, M.B.; Pivetta, L.A.; Pivetta, L.G.; Echer, M.M. 2014. Alternative substrates in the production of lettuce seedlings and their productivity in the field. Revista Ciência Agronômica 45: 299-304.
Chartzoulakis, K.; Patakas, A.; Kofidis, G.; Bosabalidis, A.; Nastou. A. 2002. Water stress affects leaf anatomy, gas exchange, water relations and growth of two avocado cultivars. Scientia Horticulturae 95: 39-50.

Chaware, D.; Raut, A.; Panse, M.; Koparkar, A. 2015. Sensor based automated irrigation system. International Journal of Engineering Research \& Technology 4: 33-37.

Costa, E.; Leal, P.A.M.; Benett, C.G.S.; Benett, K.S.S.; Salamenes, L.C.P. 2012. Production of tomato seedlings using different substrates and trays in three protected environments. Engenharia Agrícola 32: 822-830.

Christiansen, J.E. 1942. Irrigation by Sprinkling. California Agricultural Experiment Station, Berkeley, CA, USA. (Bulletin, 670).

Dai, J.; Cui, Y.; Cai, X.; Brown, L.C.; Shang, Y. 2016. Influence of water management on the water cycle in a small watershed irrigation system based on a distributed hydrologic model. Agricultural Water Management 174: 52-60.

Dias, G.C.O.; Medici, L.O.; Vasconcellos, M.A.S.; Carvalho, D.F.; Pimentel, C. 2013. Papaya seedlings growth using a low-cost automatic watering controller. Revista Brasileira de Fruticultura 35: 40-46.

Gent, M.P.N. 2007. Effect of degree and duration of shade on quality of greenhouse tomato. HortScience 42: 51.

Gomes, D.P.; Carvalho, D.F.; Pinto, M.F.; Valença, D.C.; Medici, L.O. 2017. Growth and production of tomato fertilized with ash and castor cake and under varying water depths, cultivated in organic potponics. Acta Scientiarum 39: 201-209.

Gonçalves, M.S.; Facchi, D.P.; Brandão, M.I.; Bauer, M.; Paris Júnior, O. 2014. Production of lettuce and cabbage seedlings using compost from agroindustrial residues. Revista Brasileira de Agroecologia. 9: 216-224 (in Portuguese, with abstract in English).

Herrera, F.; Castillo, J.E.; Chica, A.F.; López Bellido, L. 2008. Use of municipal solid waste compost (MSWC) as a growing medium in the nursery production of tomato plants. Bioresource Technology 99: 287-296.

Kato, Y.; Okami, M. 2011. Root morphology, hydraulic conductivity and plant water relations of high-yielding rice grown under aerobic conditions. Annals of Botany 108: 575583.

Kim, H.; Goins, G.D.; Wheeler, R.M.; Sager, J.C. 2004. Stomatal conductance of lettuce grown under or exposed to different light qualities. Annals of Botany 94: 691-697.

Leal, P.A.M.; Costa, E.; Schiavo, J.A.; Pegorare, A.B. 2011. Seedling formation and field production of beetroot and lettuce in Aquidauana, Mato Grosso do Sul, Brazil. Horticultura Brasileira 29: 465-471.

Medici, L.O.; Rocha, H.S.; Carvalho, D.F.; Pimentel, C.; Azevedo, R.A. 2010. Automatic controller to water plants. Scientia Agricola 67: 727-730.

Mojid, M.A.; Biswas, S.K.; Wyseure, G.C.L. 2012. Interaction effects of irrigation by municipal wastewater and inorganic fertilisers on wheat cultivation in Bangladesh. Field Crops Research 134: 200-207.

Nielsen, D.R.; Van Genuchten, M.Th.; Biggar, J.W. 1986. Water flow and solute transport processes in the unsaturated zone. Water Resources Research 22: 89S-108S. 
Oliveira, L.C.; Costa, E.; Cortelassi, J.A.S.; Rodrigues, E.T. 2012. Formation of beetroot seedlings in different protected environments, substrates and containers in Aquidauana region, state of Mato Grosso do Sul, Brazil. Engenharia Agrícola 32: 415-422.

Rahimi, A.; Sayadi, F.; Dashti, H.; Tajabadi pour, A. 2013. Effects of water and nitrogen supply on growth, water-use efficiency and mucilage yield of isabgol (Plantago ovata Forsk). Journal of Soil Science and Plant Nutrition 13: 341-354.

Santos, H.T.; Carvalho, D.F.; Souza, C.F.; Medici, L.O. 2015. Lettuce growing under automated irrigation and hydrogel application. Engenharia Agrícola 35: 852-862 (in Portuguese, with abstract in English).

Scalon, S.P.Q.; Mussury, R.M.; Euzébio, V.L.M.; Kodama, F.M.; Kissmann, C. 2011. Water stress in metabolism and initial growth of mutambo (Guazuma ulmifolia Lam.) seedlings. Ciência Florestal 21: 655-662 (in Portuguese, with abstract in English).
Sinclair, T.R.; Shiraiwa T.; Hammer, G.L. 1992. Variation in crop radiation use efficiency with increased diffuse radiation. Crop Science 32: 1281-1284.

Strasser, B.J.; Strasser, R.J. 1995. Measuring fast fluorescence transients to address environmental questions: the JIP test. p. 977-980. In: Mathis, P., ed. Photosynthesis: from light to biosphere. Kluwer Academic, Dordrecht, The Netherlands.

Trani, P.E.; Novo, M.C.S.S.; Cavallaro Júnior, M.L.; Telles, L.M.G. 2004. Production of lettuce seedlings in different trays and commercial substrates. Horticultura Brasileira 22: 290-294 (in Portuguese, with abstract in English).

Weih, M.; Bonosi, L.; Ghelardini, L.; Rönnberg-Wästljung, A.C. 2011. Optimizing nitrogen economy under drought: increased leaf nitrogen is an acclimation to water stress in willow (Salix spp.). Annals of Botany 108: 1347-1353. 